\title{
A Genetic Basis for Functional Hypothalamic Amenorrhea
}

\author{
Lisa M. Caronia, B.A., Cecilia Martin, Ph.D., Corrine K. Welt, M.D., Gerasimos P. Sykiotis, \\ M.D., Ph.D., Richard Quinton, M.D., Apisadaporn Thambundit, B.A., Magdalena Avbelj, \\ M.D., Ph.D., Sadhana Dhruvakumar, M.Sc., Lacey Plummer, B.A., Virginia A. Hughes, \\ M.Sc., Stephanie B. Seminara, M.D., Paul A. Boepple, M.D., Yisrael Sidis, Ph.D., William F. \\ Crowley Jr., M.D., Kathryn A. Martin, M.D., Janet E. Hall, M.D., and Nelly Pitteloud, M.D. \\ Harvard Center for Reproductive Endocrine Sciences and Reproductive Endocrine Unit and the \\ Department of Medicine, Massachusetts General Hospital - both in Boston (L.M.C., C.M., \\ C.K.W., G.P.S., A.T., M.A., S.D., L.P., V.A.H., S.B.S., P.A.B., Y.S., W.F.C., K.A.M., J.E.H., N.P.); \\ the Department of Endocrinology, Royal Victoria Infirmary, and the Institute for Human Genetics, \\ University of Newcastle upon Tyne - both in Newcastle upon Tyne, United Kingdom (R.Q.); and \\ the Endocrine Division, Centre Hospitalier Universitaire Vaudois, University of Lausanne, \\ Lausanne, Switzerland (Y.S., N.P.).
}

\section{Abstract}

BACKGROUND-Functional hypothalamic amenorrhea is a reversible form of gonadotropinreleasing hormone $(\mathrm{GnRH})$ deficiency commonly triggered by stressors such as excessive exercise, nutritional deficits, or psychological distress. Women vary in their susceptibility to inhibition of the reproductive axis by such stressors, but it is unknown whether this variability reflects a genetic predisposition to hypothalamic amenorrhea. We hypothesized that mutations in genes involved in idiopathic hypogonadotropic hypogonadism, a congenital form of GnRH deficiency, are associated with hypothalamic amenorrhea.

METHODS-We analyzed the coding sequence of genes associated with idiopathic hypogonadotropic hypogonadism in 55 women with hypothalamic amenorrhea and performed in vitro studies of the identified mutations.

\begin{abstract}
RESULTS-Six heterozygous mutations were identified in 7 of the 55 patients with hypothalamic amenorrhea: two variants in the fibroblast growth factor receptor 1 gene $F G F R I$ (G260E and R756H), two in the prokineticin receptor 2 gene PROKR2 (R85H and L173R), one in the GnRH receptor gene GNRHR (R262Q), and one in the Kall-mann syndrome 1 sequence gene $K A L 1$ (V371I). No mutations were found in a cohort of 422 controls with normal menstrual cycles. In vitro studies showed that FGFRI G260E, FGFR1 R756H, and PROKR2 R85H are lossof-function mutations, as has been previously shown for PROKR2 L173R and GNRHR R262Q.
\end{abstract}

CONCLUSIONS-Rare variants in genes associated with idiopathic hypogonadotropic hypogonadism are found in women with hypothalamic amenorrhea, suggesting that these mutations may contribute to the variable susceptibility of women to the functional changes in GnRH secretion that characterize hypothalamic amenorrhea. Our observations provide evidence for the role of rare variants in common multifactorial disease. (Funded by the Eunice Kennedy Shriver National Institute of Child Health and Human Development and others; ClinicalTrials.gov number, NCT00494169.)

Copyright @ 2011 Massachusetts Medical Society.

Address reprint requests to Dr. Pitteloud at the Endocrine Division, Centre Hospitalier Universitaire Vaudois, University of Lausanne, Rue du Bugnon 46, CH-1011 Lausanne, Switzerland, or at nelly.pitteloud@ chuv.ch..

Ms. Caronia and Dr. Martin contributed equally to this article.

Disclosure forms provided by the authors are available with the full text of this article at NEJM.org. 
Reproduction is an energetically costly process for women, and defense mechanisms have evolved that temporarily inhibit reproduction under adverse conditions. Stressors such as weight loss, 1 excessive exercise, 2 eating disorders, 3 and psychological distress ${ }^{4}$ sup-press the hypothalamic-pituitary-gonadal axis by inhibiting hypothalamic pulsatile secretion of gonadotropin-releasing hormone $(\mathrm{GnRH}){ }^{5}$ This frequent cause of female infertility is diagnosed as functional hypothalamic amenorrhea, defined as the absence of menses, low or normal gonadotropin levels, and hypoestrogenemia without organic abnormality. 6 Hypothalamic amenorrhea is associated with a spectrum of abnormal GnRH-secretion patterns, and administration of exogenous pulsatile GnRH can restore functionality of the hypothalamic-pituitary-gonadal axis.7 The exquisite sensitivity of the GnRH pulse generator to energy deficits is evidenced by the fact that serum levels of leptin, a signal of fat reserves, are often low in patients with hypothalamic amenorrhea and that leptin replacement can restore GnRH pulsatility. $8^{-10}$ After the underlying stressors have been eliminated, normal reproductive function resumes in most cases. ${ }^{11}$ Among both women and female nonhuman primates, sensitivity to the inhibition of the hypothalamic-pituitarygonadal axis by such stressors varies substantially. ${ }^{12,13}$ However, it is unknown whether this susceptibility reflects a genetic predisposition to hypothalamic amenorrhea.

Much is known about the genetics of congenital GnRH deficiency (idiopathic hypogonadotropic hypogonadism), in contrast to hypothalamic amenorrhea. Idiopathic hypogonadotropic hypogonadism is characterized by an absence of puberty and by infertility, caused by defects in the secretion of GnRH from the hypothalamus or defects in the action of GnRH on the pituitary. ${ }^{14,} 15$ The disease is genetically heterogeneous, with several associated loci that account for approximately $40 \%$ of cases. 15 The involved genes encode proteins essential for GnRH neuron development and GnRH secretion and action. $16^{-18}$ The variable expressivity of the clinical features of GnRH deficiency most likely reflects the contributions of multiple genetic defects or epigenetic perturbations. We hypothesized that mutations in genes involved in idiopathic hypogonadotropic hypogonadism confer susceptibility to the functional deficiency in GnRH secretion that characterizes hypothalamic amenorrhea.

\section{METHODS \\ STUDY PARTICIPANTS}

All participants provided written informed consent.

Controls-Controls were 422 women from the greater Boston area, recruited by means of advertising, who had undergone normal puberty (menarche at $\geq 10$ but $<15$ years), had had a normal menstrual cycle (27 to 32 days' duration) for the previous 2 years, and had a bodymass index (BMI, the weight in kilograms divided by the square of the height in meters) between 18 and 35. No predisposing factors for hypothalamic amenorrhea were reported for 375 of the 422 women; the remaining 47 exercised for more than 5 hours per week, which is a pre-disposing factor.

Patients with Hypothalamic Amenorrhea-Hypothalamic amenorrhea was diagnosed in 55 women presenting to the Massachusetts General Hospital or Newcastle upon Tyne Hospital with a history of secondary amenorrhea for 6 months or more, low or normal gonadotropin levels, low serum estradiol levels, and one or more predisposing factors. These factors included excessive exercise ( $>5$ hours per week) ${ }^{19}$ loss of more than $15 \%$ of body weight, and a subclinical eating disorder as ascertained with the use of the Eating Attitudes Test.20 None of the patients met the diagnostic criteria for anorexia nervosa at presentation. 21 
All 55 patients with hypothalamic amenorrhea had completed puberty spontaneously. The mean $( \pm \mathrm{SD})$ age at diagnosis was $22.4 \pm 6.1$ years, and the mean BMI was $19.4 \pm 2.2$. The mean age at menarche was $13.5 \pm 1.8$ years, with 13 patients reporting delayed menarche (age at onset, $\geq 15$ years) at a time when no factors predisposing them to hypothalamic amenorrhea were present. Twenty-five patients reported exercising excessively, 20 had weight loss, and 28 had a subclinical eating disorder characterized by dietary restriction and preoccupation with weight.20,21 Six patients had a family history of delayed puberty, and 9 a family history of hypothalamic amenorrhea. The mean serum levels of luteinizing hormone ( $\mathrm{LH})$, follicle-stimulating hormone (FSH), and estradiol in the group with hypothalamic amenorrhea were $4.1 \pm 3.0 \mathrm{IU}$ per liter, $6.7 \pm 3.3 \mathrm{IU}$ per liter, and $39 \pm 25 \mathrm{pg}$ per milliliter (143 \pm 92 pmol per liter), respectively. All patients had normal results on neuroimaging, and none had symptoms or biochemical signs of the polycystic ovary syndrome (hirsutism, acne, hyperandrogenemia, an LH-to-FSH ratio >1). A subgroup of the patients underwent $\mathrm{LH}$-secretion studies involving blood sampling every 10 minutes over a 24-hour period.11,22

Patients with Idiopathic Hypogonadotropic Hypogonadism-We evaluated 160 women with idiopathic hypogonadotropic hypogonadism. All had absent or incomplete puberty as of 18 years of age, low or normal serum gonadotropin levels, low serum estradiol levels, otherwise normal anterior pituitary function, and normal results on neuroimaging.

\section{GENETIC STUDIES}

Genomic DNA was extracted from peripheral-blood samples obtained from all participants. Exonic and proximal intronic sequences (located at least $15 \mathrm{bp}$ from the splice sites) of seven genes implicated in the cause of idiopathic hypogonadotropic hypogonadism were determined in all samples from patients with hypothalamic amenorrhea: the Kallmann syndrome 1 sequence gene $K A L 1,{ }^{23}$ the GnRH receptor gene $G N R H R{ }^{24}$ the G proteincoupled receptor 54 gene GPR54,25 the fibroblast growth factor receptor 1 gene $F G F R 1^{, 26}$ the fibroblast growth factor 8 gene $F G F 8,27$ the prokineticin 2 gene $P R O K 2,28$ and the prokineticin receptor 2 gene $P R O K R 2 .{ }^{29}$ Sequence variations were found on both strands and were confirmed in separate polymerase-chain-reaction assays. No rare sequence variants were found in a cohort of 422 controls with normal menstrual cycles.

\section{FUNCTIONAL CHARACTERIZATION OF NEW FGFR1 AND PROKR2 MUTATIONS}

Gene-Reporter Assays-The FGFR1 G260E and R756H mutations and the PROKR2 $\mathrm{R} 85 \mathrm{H}$ mutation were introduced into previously described expression vectors by means of a QuickChange XLII Kit (Stratagene)28,29 and were studied in L6 myoblasts and human embryonic kidney (HEK) 293 cells, respectively. The ability to activate downstream signaling was compared between the mutated receptor and its wild-type counterpart in transient transfection assays, as previously described.29,30 The osteocalcin fibroblast growth factor (FGF) response element (OCFRE) reporter and the murine early growth response 1 (Egr-1) reporter served as indicators of FGFR1-induced and PROKR2-induced mitogen-activated protein kinase (MAPK) signaling, respectively. Each assay was performed twice in triplicate. Four-parameter sigmoidal dose-response curves were generated and analyzed with the use of Prism 4 statistical software (GraphPad).

Total Expression and Cell-Surface-Receptor Expression-Total expression of wild-type and mutant FGFR1 and PROKR2 transfected into COS-7 cells was determined by means of Western blotting involving whole-cell extracts, as previously described.29,30 The cell-surface expression of FGFR1 was quantified as previously described, ${ }^{30}$ and the cellsurface expression of PROKR2 was also quantified, with the use of a 3xHA tag sequence fused with the N-terminal end of PROKR 2 to facilitate recognition by the antibody (Clone 
HA-7, Sigma). Antibody-binding assays were performed three times in quadruplicate. Expression levels of mutant and wild-type receptors were compared by means of Student's two-tailed t-test.

\section{RESULTS}

Heterozygous mutations in genes associated with idiopathic hypogonadotropic hypogonadism (FGFR1, PROKR2, GNRHR, and KAL1) were identified in 7 of the 55 patients with hypothalamic amenorrhea (13\%; 95\% confidence interval, 5 to 24$)$ (Fig. 1 and Table 1). All 7 patients were white, as reported by study physicians. These genetic variants were absent among the controls (the 375 women without risk factors for hypothalamic amenorrhea and the 47 women who exercised $>5$ hours per week). The variants alter amino acids that are highly conserved across species (Fig. 2C, 2D, and 2E) and cause considerable loss of function, ${ }^{29,31,32}$ findings that are consistent with disease-associated mutations.

FGFR1 mutants (G260E and R756H) in the ligand domain and tyrosine kinase domain of the receptor, respectively, were found in Patients 1 and 2. The FGFR1 G260E and R756H mutants showed expression levels similar to those of wild-type FGFR1, both overall (Fig. 2F and $2 \mathrm{G}$ ) and on the cell surface (Fig. 2I and 2J). However, results of a transcriptional assay show that the G260E and R756H mutants result in loss of function, as demonstrated by a decrease in FGF-induced MAPK reporter activity (reflected by OCFRE activity) $(\mathrm{P}<0.001)$ (Fig. 2L and 2M).

The PROKR2 mutant R85H identified in Patient 3 is also a loss-of-function mutant, as evidenced by decreased overall and cell-surface expression decreased signaling activity as compared wild-type PROKR2 ( $\mathrm{P}<0.001$ for cell-surface expression and signaling activity) (Fig. 2H, and 2N). ${ }^{31}$ The PROKR2 L173R mutant seen Patient 4 and the GNRHR R262Q mutant in Patients 5 and 6 have previously been reported loss-of-function mutants (Table 2). 29,31,32 Finally, characteristics of the KAL1 V371I mutant in Patient 7 could not be assessed (Table 2) owing the scarcity of in vitro functional assays available for KAL1.

All seven patients with hypothalamic amenorrhea who had mutations had secondary amenorrhea for at least 6 months and at least one factor for hypothalamic amenorrhea (Table Four of the seven reported a family history of hypothalamic amenorrhea or delayed puberty (Fig. 1 and Table 2). Among the seven patients, the age at diagnosis ranged from 18 to 34 years (mean, 24.4 \pm 6.2 ), and the BMI at diagnosis ranged from 18 to 22 (mean, 19.4 \pm 1.9 ). Four of the seven patients had attempted to conceive; three of the attempts were successful, with one patient conceiving without assisted reproductive treatment. Two of the seven patients continued to receive long-term hormone-replacement therapy. The other five discontinued hormonal therapy and had recovery of menses. A more detailed summary of the seven patients is given in the Supplementary Appendix (available with the full text of this article at NEJM.org).

Our patients with hypothalamic amenorrhea who had the PROKR2 R85H or FGFR1 R756H mutation also had abnormal patterns of endogenous GnRH-induced LH secretion (Fig. 3).

\section{DISCUSSION}

We found genetic defects in several patients with hypothalamic amenorrhea. The affected genes play fundamental roles in GnRH ontogeny and function: GNRHR encodes the unique receptor that is activated by gonadotropin-releasing hormone $1(\mathrm{GnRH} 1)$ in the pituitary ${ }^{33}$; $K A L 1$ and $P R O K R 2$ are critical for the migration of GnRH-secreting neurons ${ }^{34,35}$; and $F G F R 1$ controls the fate specification, migration, and survival of GnRH-secreting neurons. ${ }^{17}$ In humans, mutations in these genes underlie severe congenital GnRH deficiency 
(idiopathic hypogonadotropic hypogonadism). ${ }^{15}$ In fact, the GNRHR R262Q mutation and the PROKR2 R85H and L173R mutations described here have previously been associated with idiopathic hypogonadotropic hypogonadism. ${ }^{29,31,32,36,37}$

Patients who had hypothalamic amenorrhea as well as the PROKR2 R85H or FGFR1 $\mathrm{R} 756 \mathrm{H}$ mutation in our study were also shown to have abnormal patterns of endogenous GnRH-induced LH secretion, as previously described in women with hypothalamic amenorrhea. ${ }^{7}$ We speculate that decreased PROKR2 or FGFR1 signaling leads to a partially compromised GnRH neuronal network owing to a smaller-than-normal number of GnRHproducing cells that have successfully completed embryonic migration to the hypothalamus, a suboptimal maturation of the GnRH network during puberty, or a defective regulation of GnRH secretion - since both proteins are expressed not only during development but also in the adult hypothalamus. ${ }^{16,28}$ This would, in turn, predispose persons to abnormal GnRH secretion under the influence of factors that stress the reproductive system. FGFR1 and PROKR2 signaling also modifies eating behavior in mice. ${ }^{38,39}$ Thus, we speculate that genetic defects in these pathways may also contribute to the abnormal eating patterns seen in many patients with hypothalamic amenorrhea.

We found that genes mutated in patients with idiopathic hypogonadotropic hypogonadism also are mutated in those with hypothalamic amenorrhea. This finding expands our understanding of the genetics of GnRH-deficiency disorders. Idiopathic hypogonadotropic hypogonadism was traditionally considered a genetically determined, congenital, and lifelong form of GnRH deficiency. However, as many as $10 \%$ of patients with idiopathic hypogonadotropic hypogonadism resume normal reproductive function after treatment is discontinued, even if they have genetic defects. ${ }^{40}$ This reversal of idiopathic hypogonadotropic hypogonadism indicates the plasticity of the GnRH network and its sensitivity to nongenetic factors. Conversely, idiopathic hypogonadotropic hypogonadism occasionally is present in adult men (in which case it is called adult-onset idiopathic hypogonadotropic hypogonadism). ${ }^{41}$ Some men with the disease who carry mutations in genes underlying idiopathic hypogonadotropic hypogonadism 27 have normal reproductive function before onset, suggesting that their GnRH deficiency results from a combination of genetic and environmental influences.

In contrast to idiopathic hypogonadotropic hypogonadism, hypothalamic amenorrhea has been traditionally viewed as a functional form of GnRH deficiency resulting from insufficient energy availability, psychological stress, or both. Studies of humans and nonhuman primates have shown that stress can induce reproductive dys-function, including amenorrhea, in many, although not all, females with normal menstrual cycles. ${ }^{12,13,19}$ Our findings may help to explain the variable susceptibility of women to inhibition of the hypothalamic-pituitary-gonadal axis. Since patients with mutations resumed regular menses after discontinuing hormone-replacement therapy, the genetic component of hypothalamic amenorrhea predisposes one to, but is not sufficient to cause, GnRH deficiency.

If hypothalamic amenorrhea has a genetic basis partially in common with idiopathic hypogonadotropic hypogonadism, what are the factors that ultimately generate these divergent clinical phenotypes? The total load of mutations in genes related to GnRH ontogeny and action might be less in hypothalamic amenorrhea than in idiopathic hypogonadotropic hypogonadism. Patients with idiopathic hypogonadotropic hypogonadism frequently show homozygosity and compound heterozygosity for mutations at the diseasecausing loci. ${ }^{25,32,36,42}$ Furthermore, digenic inheritance of mutations associated with idiopathic hypogonadotropic hypogonadism (FGFR1 in combination with GNRHR,NELF [the gene encoding the nasal embryonic LH-releasing hormone factor], or PROKR2, or other digenic pairs) has been reported. ${ }^{30,36,37,43}$ 
All six mutations associated with hypothalamic amenorrhea in our study were heterozygous. We speculate that such heterozygous mutations, while not sufficient to cause idiopathic hypogonadotropic hypogonadism, could set a lower threshold for functional inhibition of the hypothalamic-pituitary-gonadal axis under adverse hormonal, nutritional, or psychological conditions and thereby lead to hypothalamic amenorrhea. Such a lower threshold for inhibition might also confer a selective advantage to female carriers during famine, helping to balance survival against the metabolic needs of pregnancy. This explanation would be consistent with the presence of mutations associated with idiopathic hypogonadotropic hypogonadism and hypothalamic amenorrhea in persons who do not have symptoms. The PROKR2 L173R mutation appears to be an example: it has been reported in more than a dozen patients with idiopathic hypogonadotropic hypogonadism, mostly in the heterozygous state, and in many of these cases was inherited from an asymptomatic parent. $9,31,36,37$

To elucidate the genetics of hypothalamic amenorrhea more completely, it will be important to undertake comprehensive sequencing of the genes associated with idiopathic hypogonadotropic hypogonadism in larger cohorts of patients with hypothalamic amenorrhea. Twenty-five percent of women with hypothalamic amenorrhea in our study had a history of delayed puberty, which is frequently seen in family members of patients with idiopathic hypogonadotropic hypogonadism. It may be worthwhile to investigate whether rare variants in genes underlying idiopathic hypogonadotropic hypogonadism or hypothalamic amenorrhea also contribute to delayed puberty.

Genetic defects within pathways controlling appetite or stress-response systems might also contribute to hypothalamic amenorrhea. The genetic susceptibility to anorexia or bulimia nervosa has been investigated in several association studies that examined candidate genes such as brain-derived neurotrophic factor, neurotrophic tyrosine kinase receptor types 2 and 3 , serotonin, leptin, and hypocretin. ${ }^{44,45}$ Unlike our study, which sought rare genetic variants, the prior studies focused on common DNA polymorphisms. The results have been largely inconclusive, most likely owing to small sample sizes, heterogeneity in race and ethnic group, and variation in diagnostic criteria. It might prove more fruitful to investigate whether rare variants in genes associated with the response to stress and starvation also contribute to susceptibility to hypothalamic amenorrhea.

In conclusion, we demonstrated that patients with hypothalamic amenorrhea have mutations in genes regulating $\mathrm{GnRH}$ ontogeny and action. Given the limited size of the cohort with hypothalamic amenorrhea, we would not recommend that women with hypothalamic amenorrhea be routinely screened for mutations at loci known to underlie idiopathic hypogonadotropic hypogonadism, except in cases of clear familial inheritance of hypothalamic amenorrhea or idiopathic hypogonadotropic hypogonadism. Further elucidation of the genetic basis of hypothalamic amenorrhea and delineation of the relationship among genotype, environment, and phenotype are needed.

\section{Supplementary Material}

Refer to Web version on PubMed Central for supplementary material.

\section{Acknowledgments}

Supported by the Eunice Kennedy Shriver National Institute of Child Health and Human Development (NICHD) of the National Institutes of Health (NIH) (through cooperative agreement 5U54HD028138 as part of the Specialized Cooperative Centers Program in Reproduction and Infertility Research and NICHD-NIH grants 1R01HD056264, 5R01HD015788, and 5R01HD42708), by the National Center for Research Resources (grants 1 UL1 RR025758-01 and M01-RR-01066 to the Harvard Clinical and Translational Science Center), the Newcastle University Teaching Hospitals Special Trustees, and the Pew Latin American Fellows Program in the Biomedical Sciences (grant to Dr. Martin). 


\section{REFERENCES}

1. Frisch RE, McArthur JW. Menstrual cycles: fatness as a determinant of minimum weight for height necessary for their maintenance or onset. Science 1974;185:949-51. [PubMed: 4469672]

2. Warren MP. The effects of exercise on pubertal progression and reproductive function in girls. $\mathbf{J}$ Clin Endocrinol Metab 1980;51:1150-7. [PubMed: 6775000]

3. Boyar RM, Katz J, Finkelstein JW, et al. Anorexia nervosa: immaturity of the 24-hour luteinizing hormone secretory pattern. N Engl J Med 1974;291:861-5. [PubMed: 4412035]

4. Giles DE, Berga SL. Cognitive and psychiatric correlates of functional hypothalamic amenorrhea: a controlled comparison. Fertil Steril 1993;60:486-92. [PubMed: 8375531]

5. Loucks AB, Mortola JF, Girton L, Yen SS. Alterations in the hypothalamicpituitary-ovarian and the hypothalamic-pituitary-adrenal axes in athletic women. J Clin Endocrinol Metab 1989;68:402-11. [PubMed: 2537332]

6. Reindollar RH, Novak M, Tho SP, McDonough PG. Adult-onset amenorrhea: a study of 262 patients. Am J Obstet Gynecol 1986;155:531-43. [PubMed: 3529965]

7. Santoro N, Filicori M, Crowley WF Jr. Hypogonadotropic disorders in men and women: diagnosis and therapy with pulsatile gonadotropin-releasing hormone. Endocr Rev 1986;7:11-23. [PubMed: 3082615]

8. Loucks AB, Thuma JR. Luteinizing hormone pulsatility is disrupted at a threshold of energy availability in regularly menstruating women. J Clin Endocrinol Metab 2003;88:297-311. [PubMed: 12519869]

9. Miller KK, Parulekar MS, Schoenfeld E, et al. Decreased leptin levels in normal weight women with hypothalamic amenorrhea: the effects of body composition and nutritional intake. J Clin Endocrinol Metab 1998;83:2309-12. [PubMed: 9661600]

10. Welt CK, Chan JL, Bullen J, et al. Recombinant human leptin in women with hypothalamic amenorrhea. N Engl J Med 2004;351:987-97. [PubMed: 15342807]

11. Perkins RB, Hall JE, Martin KA. Aetiology, previous menstrual function and patterns of neuroendocrine disturbance as prognostic indicators in hypothalamic amenorrhoea. Hum Reprod 2001;16:2198-205. [PubMed: 11574516]

12. Bullen BA, Skrinar GS, Beitins IZ, von Mering G, Turnbull BA, McArthur JW. Induction of menstrual disorders by strenuous exercise in untrained women. N Engl J Med 1985;312:1349-53. [PubMed: 3990734]

13. Centeno ML, Sanchez RL, Cameron JL, Bethea CL. Hypothalamic gonadotrophin-releasing hormone expression in female monkeys with different sensitivity to stress. J Neuroendocrinol 2007;19:594-604. [PubMed: 17620101]

14. Seminara SB, Hayes FJ, Crowley WF Jr. Gonadotropin-releasing hormone deficiency in the human (idiopathic hypogonadotropic hypogonadism and Kallmann's syndrome): pathophysiological and genetic considerations. Endocr Rev 1998;19:521-39. [PubMed: 9793755]

15. Bianco SD, Kaiser UB. The genetic and molecular basis of idiopathic hypogonadotropic hypogonadism. Nat Rev Endocrinol 2009;5:569-76. [PubMed: 19707180]

16. Chung WC, Moyle SS, Tsai PS. Fibro-blast growth factor 8 signaling through fibroblast growth factor receptor 1 is required for the emergence of gonadotropin-releasing hormone neurons. Endocrinology 2008;149:4997-5003. [PubMed: 18566132]

17. Kim SH, Hu Y, Cadman S, Bouloux P. Diversity in fibroblast growth factor receptor 1 regulation: learning from the investigation of Kallmann syndrome. J Neuroendocrinol 2008;20:141-63. [PubMed: 18034870]

18. Seminara SB, Crowley WF Jr. Kiss-peptin and GPR54: discovery of a novel pathway in reproduction. J Neuroendocrinol 2008;20:727-31. [PubMed: 18601695]

19. Thome JL, Espelage DL. Obligatory exercise and eating pathology in college females: replication and development of a structural model. Eat Behav 2007;8:334-49. [PubMed: 17606231]

20. Garner DM, Olmsted MP, Bohr Y, Garfinkel PE. The Eating Attitudes Test: psychometric features and clinical correlates. Psychol Med 1982;12:871-8. [PubMed: 6961471]

21. Wilfley DE, Bishop ME, Wilson GT, Agras WS. Classification of eating disorders: toward DSMV. Int J Eat Disord 2007;40(Suppl):S123-S129. [PubMed: 17685383] 
22. Hayes FJ, McNicholl DJ, Schoenfeld D, Marsh EE, Hall JE. Free alpha-subunit is superior to luteinizing hormone as a marker of gonadotropin-releasing hormone despite desensitization at fast pulse frequencies. J Clin Endocrinol Metab 1999;84:1028-36. [PubMed: 10084591]

23. Oliveira LM, Seminara SB, Beranova M, et al. The importance of autosomal genes in Kallmann syndrome: genotypephenotype correlations and neuroendocrine characteristics. J Clin Endocrinol Metab 2001;86:1532-8. [PubMed: 11297579]

24. Beranova M, Oliveira LM, Bédécarrats GY, et al. Prevalence, phenotypic spectrum, and modes of inheritance of gonadotropin-releasing hormone receptor mutations in idiopathic hypogonadotropic hypogonadism. J Clin Endocrinol Metab 2001;86:1580-8. [PubMed: 11297587]

25. Seminara SB, Messager S, Chatzidaki EE, et al. The GPR54 gene as a regulator of puberty. N Engl J Med 2003;349:1614-27. [PubMed: 14573733]

26. Pitteloud N, Acierno JS Jr, Meysing AU, Dwyer AA, Hayes FJ, Crowley WF Jr. Reversible Kallmann syndrome, delayed puberty, and isolated anosmia occurring in a single family with a mutation in the fibroblast growth factor receptor 1 gene. J Clin Endocrinol Metab 2005;90:131722. [PubMed: 15613419]

27. Falardeau J, Chung WC, Beenken A, et al. Decreased FGF8 signaling causes deficiency of gonadotropin-releasing hormone in humans and mice. J Clin Invest 2008;118:2822-31. [PubMed: 18596921]

28. Pitteloud N, Zhang C, Pignatelli D, et al. Loss-of-function mutation in the prokineticin 2 gene causes Kallmann syndrome and normosmic idiopathic hypogonadotropic hypogonadism. Proc Natl Acad Sci U S A 2007;104:17447-52. [PubMed: 17959774]

29. Cole LW, Sidis Y, Zhang C, et al. Mutations in prokineticin 2 and prokineticin receptor 2 genes in human gonadotrophin-releasing hormone deficiency: molecular genetics and clinical spectrum. $\mathrm{J}$ Clin Endocrinol Metab 2008;93:3551-9. [PubMed: 18559922]

30. Raivio T, Sidis Y, Plummer L, et al. Impaired fibroblast growth factor receptor 1 signaling as a cause of normosmic idiopathic hypogonadotropic hypogonadism. J Clin Endocrinol Metab 2009;94:4380-90. [PubMed: 19820032]

31. Monnier C, Dodé C, Fabre L, et al. PROKR2 missense mutations associated with Kallmann syndrome impair receptor signalling activity. Hum Mol Genet 2009;18:75-81. [PubMed: 18826963]

32. de Roux N, Young J, Misrahi M, et al. A family with hypogonadotropic hypogonadism and mutations in the gonadotropin-releasing hormone receptor. N Engl J Med 1997;337:1597-602. [PubMed: 9371856]

33. Cheng CK, Leung PC. Molecular biology of gonadotropin-releasing hormone (GnRH)-I, GnRH-II, and their receptors in humans. Endocr Rev 2005;26:283-306. [PubMed: 15561800]

34. Schwanzel-Fukuda M, Bick D, Pfaff DW. Luteinizing hormone-releasing hormone (LHRH)expressing cells do not migrate normally in an inherited hypogonadal (Kallmann) syndrome. Brain Res Mol Brain Res 1989;6:311-26. [PubMed: 2687610]

35. Matsumoto S, Yamazaki C, Masumoto KH, et al. Abnormal development of the olfactory bulb and reproductive system in mice lacking prokineticin receptor PKR2. Proc Natl Acad Sci U S A 2006;103:4140-5. [PubMed: 16537498]

36. Dodé C, Teixeira L, Levilliers J, et al. Kallmann syndrome: mutations in the genes encoding prokineticin-2 and prokineticin receptor-2. PLoS Genet 2006;2(10):e175. [PubMed: 17054399]

37. Canto P, Munguía P, Söderlund D, Castro JJ, Méndez JP. Genetic analysis in patients with Kallmann syndrome: coexistence of mutations in prokineticin receptor 2 and KAL1. J Androl 2009;30:41-5. [PubMed: 18723471]

38. Gardiner JV, Bataveljic A, Patel NA, et al. Prokineticin 2 is a hypothalamic neuropeptide that potently inhibits food in-take. Diabetes 2010;59:397-406. [PubMed: 19933997]

39. Sun HD, Malabunga M, Tonra JR, et al. Monoclonal antibody antagonists of hypothalamic FGFR1 cause potent but reversible hypophagia and weight loss in rodents and monkeys. Am J Physiol Endocrinol Metab 2007;292(3):E964-E976. [PubMed: 17132826]

40. Raivio T, Falardeau J, Dwyer A, et al. Reversal of idiopathic hypogonadotropic hypogonadism. N Engl J Med 2007;357:863-73. [PubMed: 17761590] 
41. Nachtigall LB, Boepple PA, Pralong FP, Crowley WF Jr. Adult-onset idiopathic hypogonadotropic hypogonadism — a treatable form of male infertility. N Engl J Med 1997;336:410-5. [PubMed: 9010147]

42. de Roux N, Genin E, Carel JC, Matsuda F, Chaussain JL, Milgrom E. Hypogonadotropic hypogonadism due to loss of function of the KiSS1-derived peptide receptor GPR54. Proc Natl Acad Sci U S A 2003;100:10972-6. [PubMed: 12944565]

43. Pitteloud N, Quinton R, Pearce S, et al. Digenic mutations account for variable phenotypes in idiopathic hypogonadotropic hypogonadism. J Clin Invest 2007;117:457-63. [PubMed: 17235395]

44. Mercader JM, Ribasés M, Gratacòs M, et al. Altered brain-derived neurotrophic factor blood levels and gene variability are associated with anorexia and bulimia. Genes Brain Behav 2007;6:706-16. [PubMed: 17376155]

45. Mercader JM, Saus E, Agüera Z, et al. Association of NTRK3 and its interaction with NGF suggest an altered cross-regulation of the neurotrophin signaling pathway in eating disorders. Hum Mol Genet 2008;17:1234-44. [PubMed: 18203754] 


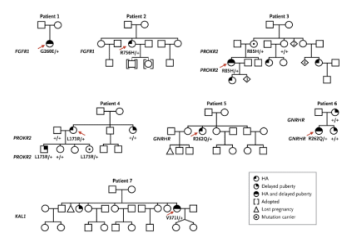

Figure 1. Pedigrees of the Seven Patients with Hypothalamic Amenorrhea (HA) Found to Have Mutations

For each pedigree, the patient with the mutation is indicated by a red arrow. The mutated gene is indicated in bold to the left of the pedigree, and the allele status is given below the proband or affected family members, with plus signs indicating wild-type and G260E, R756H, R85H, L173R, R262Q, and V371I indicating the amino acid mutations. Squares indicate male family members, circles female family members, and diamonds offspring whose sex is not shown (with the numbers of persons given within the diamond). 


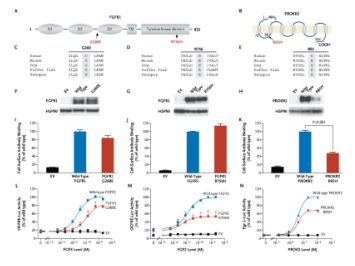

Figure 2. Loss-of-Function Mutations in Patients with Hypothalamic Amenorrhea Panels A and B show the structures of FGFR1 and PROKR2, respectively, as well as the mutations of interest. Panels C, D, and E show that the FGFR1 G260 and R756 amino acids and the PROKR2 R85 amino acid are highly conserved across vertebrate species. Panels F, $\mathrm{G}$, and $\mathrm{H}$ show that the overall expression levels of FGFR1 G260E and R756H were normal, whereas PROKR2 R85H expression levels were decreased ( $\mathrm{P}<0.01)$, as compared with wildtype levels. Heat-shock protein 90 (HSP90) was a positive control for gel loading. An empty vector $(\mathrm{EV})$ was used as a negative control for protein expression. Panels I, J, and K show that the receptor cell-surface expression levels in COS-7 cells were similar to the wild-type levels for both FGFR1 mutants but were significantly decreased for PROKR2 R85H $(\mathrm{P}<0.001)$. Panels L, M, and N show that the FGFR1 G260E mutant has decreased fibroblast growth factor 8 (FGF8)-induced osteocalcin FGF response element (OCFRE) activity as compared with the wild type $(\mathrm{P}<0.001)$, that the FGFR1 R756H mutant has decreased FGF2-induced OCFRE activity as compared with the wild type $(\mathrm{P}<0.001)$, and that the PROKR2 R85H mutant has decreased PROK2-induced early growth response 1 (Egr-1) activity as compared with the wild type $(\mathrm{P}<0.001)$. D1, D2, and D3 denote the ligandbinding domains of FGFR1; Luc the lucifer-ase reporter vector; and TM the transmembrane domain of FGFR1. T and I bars indicate standard errors of the means of two experiments performed in triplicate for the gene-reporter assays or the means of three experiments performed in quadruplicate for the antibody-binding assays. 


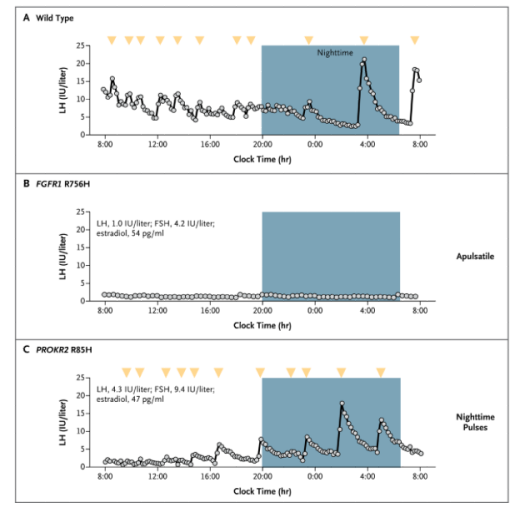

Figure 3. Patterns of Luteinizing Hormone (LH) Secretion over a 24-Hour Period, According to Mutation Status

The pattern of LH secretion induced by endogenous gonadotropin-releasing hormone in the early follicular phase of the menstrual cycle is shown as a normal, pulsatile pattern in a healthy woman (Panel A), as apulsatile in a patient with hypothalamic amenorrhea and the FGFR1 R756H mutation (Panel B), and as both apulsatile and pulsatile with increasing amplitude during the night in a patient with the PROKR2 R85H mutation (Panel C). Arrowheads indicate peaks in secretion (of which there are none in the apulsatile pattern in Panel B). Mean levels of LH, follicle-stimulating hormone (FSH), and estradiol are listed for the two patients. To convert values for estradiol to picomoles per liter, multiply by 3.671 . 


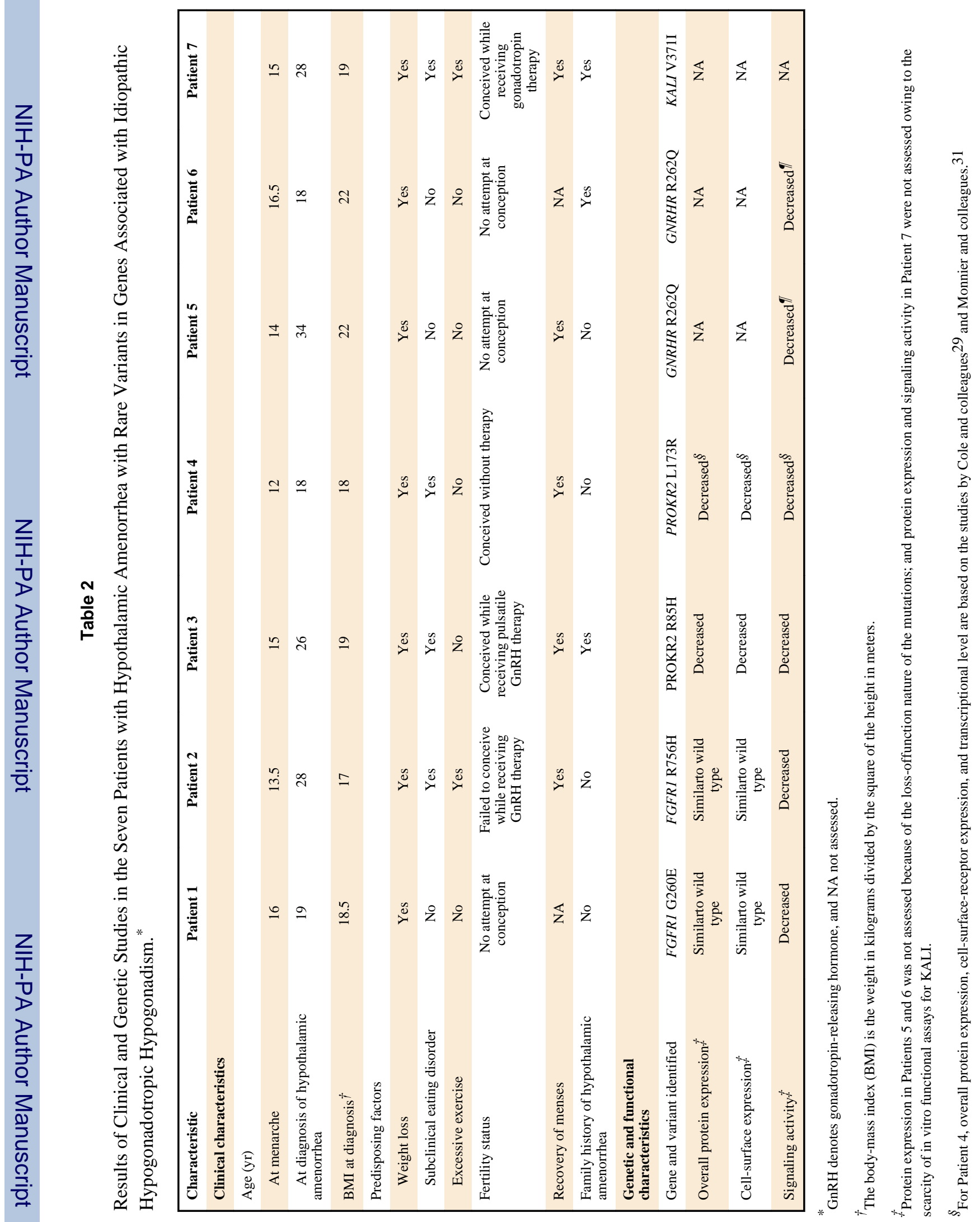

N Engl J Med. Author manuscript; available in PMC 2011 July 20. 
